Portland State University

PDXScholar

6-17-2020

\title{
A Multivariate Assessment of Climate Change Projections Over South America Using CMIP5
}

Valerie Maria Thaler

Portland State University

Follow this and additional works at: https://pdxscholar.library.pdx.edu/open_access_etds

Part of the Geography Commons

Let us know how access to this document benefits you.

\section{Recommended Citation}

Thaler, Valerie Maria, "A Multivariate Assessment of Climate Change Projections Over South America Using CMIP5" (2020). Dissertations and Theses. Paper 5550.

https://doi.org/10.15760/etd.7424

This Thesis is brought to you for free and open access. It has been accepted for inclusion in Dissertations and Theses by an authorized administrator of PDXScholar. Please contact us if we can make this document more accessible: pdxscholar@pdx.edu. 
A Multivariate Assessment of Climate Change Projections over South America using

\title{
CMIP5
}

by

Valerie Maria Thaler

A thesis submitted in partial fulfillment of the requirements for the degree of

\author{
Master of Science \\ in \\ Geography
}

Thesis Committee:

Paul Loikith, Chair

Andrew Martin

Andrés Holz

Portland State University

2020 


\begin{abstract}
A multivariate assessment of climate model projections over South America from the CMIP5 archive is presented. Change in near-surface temperature, precipitation, evapotranspiration, integrated water vapor transport (IVT), sea level pressure, and wind at multiple pressure levels is quantified across the multi-model suite and an assessment of model-to-model agreement on projected change performed. All models project warming by the mid- and late- $21^{\text {st }}$ century throughout the continent, with the highest magnitude projected over tropical regions. The CMIP5 models are in strong agreement that precipitation will decrease in all seasons over portions of Patagonia, especially along the northern portions of the current-climate mid-latitude storm track. This is consistent with a robustly projected poleward shift of the Pacific extratropical high and mid-latitude storm track indicated by a systematic increase in sea level pressure and decrease in westerly wind over Patagonia. Decreased precipitation for the months of September, October, and November is also projected, with strong model agreement, over portions of northern and northeastern Brazil, coincident with decreases in sea level pressure and increases in evapotranspiration. IVT is broadly projected to decrease over southern South America, coincident with the projected poleward shift of the mid-latitude storm track indicators, with increases projected in the vicinity of the South Atlantic Convergence Zone in austral spring and summer. Further decomposition of the thermodynamic and dynamic components to this change in IVT indicate that the projected decreases in the midlatitudes are primarily driven by changes in circulation (i.e. dynamic) while the subtropical and tropical changes have a predominantly thermodynamic origin. Results
\end{abstract}


provide a comprehensive picture of climate change across South America and highlight where projections should be interpreted with the most confidence. 


\section{Table of Contents}

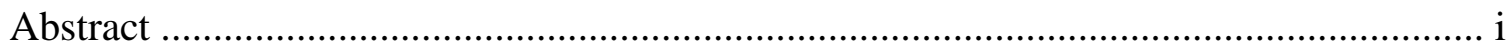

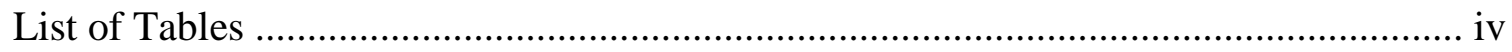

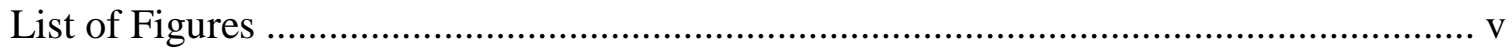

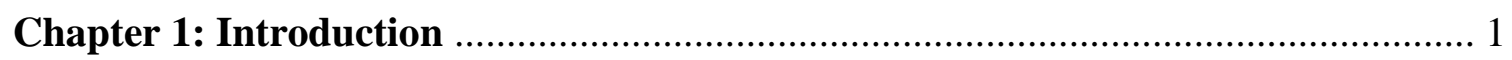

1.1 Climatology and Physical Geography of South America .................. 1

1.2 Previous Climate Model Research Over South America ..................... 3

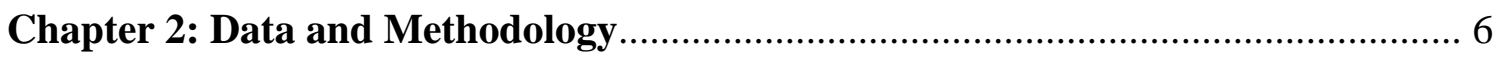

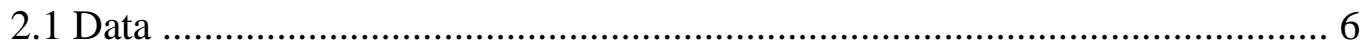

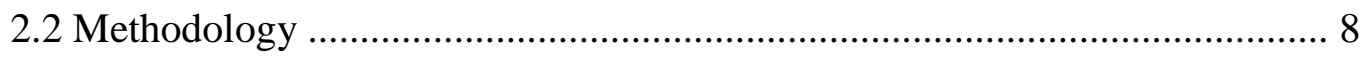

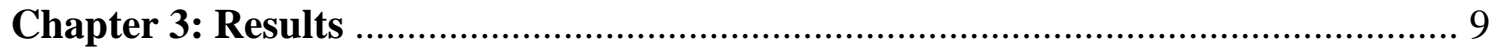

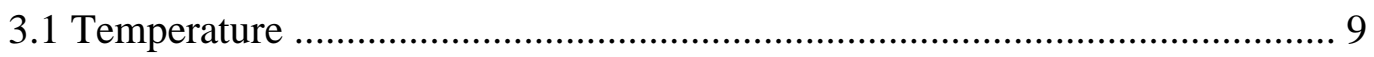

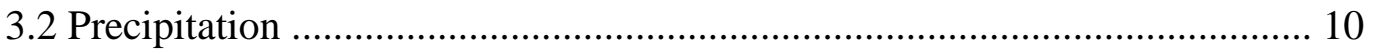

3.3 Sea Level Pressure ........................................................................... 14

3.4 Integrated Water Vapor Transport ..................................................... 16

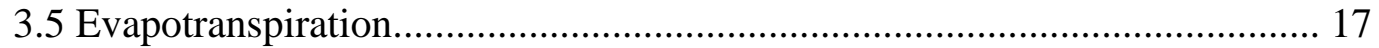

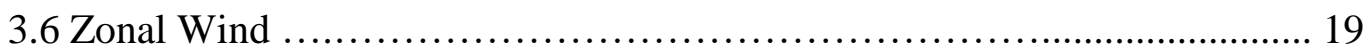

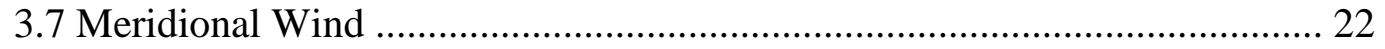

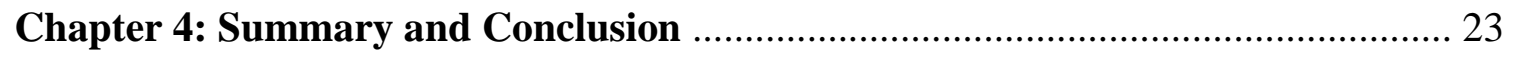

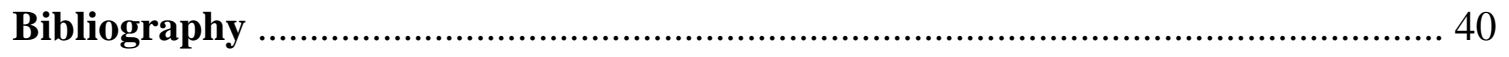




\section{List of Tables}

Table 1. CMIP5 models used and their native resolution ........................... 27 


\section{List of Figures}

Figure 1. Multi-model ensemble of projected temperature change with standard deviation of model projections overlaid 28

Figure 2. Multi-model ensemble of projected precipitation change (a-d) and model agreement (e-h) 29

Figure 3. Multi-model ensemble of projected sea level pressure change (a-d) and model agreement (e-h) 30

Figure 4. Multi-model ensemble of projected integrated water vapor transport change (ad) and model agreement (e-h) 31

Figure 5. Multi-model ensemble of projected evapotranspiration change (a-d) and model agreement (e-h)

Figure 6. Multi-model ensemble of zonal wind climatology with projected change overlaid at $850 \mathrm{hPa}(\mathrm{a}-\mathrm{d})$ and model agreement (e-h)

Figure 7. Multi-model ensemble of zonal wind climatology with projected change overlaid at $500 \mathrm{hPa}(\mathrm{a}-\mathrm{d})$ and model agreement (e-h)

Figure 8. Multi-model ensemble of zonal wind climatology with projected change overlaid at $250 \mathrm{hPa}(\mathrm{a}-\mathrm{d})$ and model agreement (e-h)

Figure 9. Multi-model ensemble of meridional wind climatology with projected change overlaid at $850 \mathrm{hPa}(\mathrm{a}-\mathrm{d})$ and model agreement (e-h) 36 
Figure 10. Multi-model ensemble of meridional wind climatology with projected change overlaid at $500 \mathrm{hPa}(\mathrm{a}-\mathrm{d})$ and model agreement (e-h)

Figure 11. Multi-model ensemble of meridional wind climatology with projected change

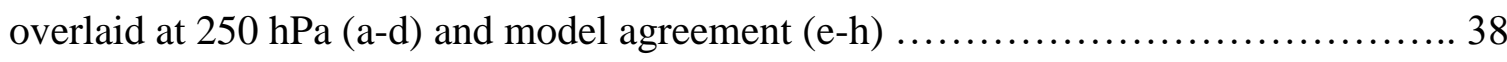

Figure 12. Summary of projected changes .................................... 39 


\section{Introduction}

The continent of South America extends from $15^{\circ} \mathrm{N}$ to $60^{\circ} \mathrm{S}$ latitude and exhibits a vast variety of climate zones. In recent decades, temperatures over South America have been increasing (de Barros Soares et al. 2017; Barkhordarian et al. 2018; Vincent et al. 2005), and many areas are already experiencing and will continue to experience the effects of anthropogenic climate change in different ways. While projected changes in temperature and precipitation have been estimated for South America, past studies have not investigated the mechanisms responsible for those changes or focused on uncertainties. This is a gap in understanding that leads to lower confidence in projected change and less granular understanding of how the changes may impact sectors such as agriculture and human health. Therefore, it is important to examine and gain a comprehensive understanding of climate change and the associated uncertainties over South America.

\section{Climatology and Physical Geography of South America}

In northern South America, there is the expansive tropical Amazon rainforest which resides in the world's largest river basin, the Amazon Basin. The Amazon rainforest is home to the highest biodiversity on the planet but is threatened by deforestation for agricultural expansion and cattle production. Globally, forests and other vegetation remove up to $30 \%$ of human carbon dioxide emissions from the atmosphere during photosynthesis (Espinoza 2015). Therefore, the process of biomass burning to clear tropical rainforests for agricultural production reverses their natural ability to absorb the already increasing amounts of carbon dioxide in the atmosphere and releases it back 
into the atmosphere (Marengo et al. 2018). As of 2013, it has been suggested that $1.5 \%$ of the recent increase in atmospheric carbon dioxide can be attributed to deforestation in the Amazon since the beginning of the industrial era (Exbrayat and Williams 2015).

Annually, the Amazon averages about $2400 \mathrm{~mm}$ of precipitation, and the South American monsoon system (SAMS) plays an integral role in supporting the extreme moisture of this area. Water vapor originating in this region is transported poleward by a low-level jet along the east side of the Andes (Marengo et al. 2004), supporting deep convection over La Plata basin, the world's fifth largest river basin (Garreaud et al. 2009). La Plata basin is known for being home to some of the most intense thunderstorms on Earth (Zipser et al. 2006).

Looking closer at changes in this region of South America, Zilli et al. (2019) analyzed the mechanisms behind the changes in the precipitation intensity and position of a component of the SAMS, the South Atlantic Convergence Zone (SACZ) and found that there has been a observed poleward shift in its mean location. The SACZ is characterized as a diagonally-oriented band of convection that extends from tropical South America southeastward towards the southeast Brazilian coast which is formed by low-level convergence of winds and moisture transport from the Amazon toward the subtropical South Atlantic Ocean (de Carvalho and Cavalcanti 2016). The SACZ is an important climatological feature in South America because it provides more than $50 \%$ of the annual total precipitation for the densely populated central-eastern and southeastern regions of Brazil. Therefore, the SACZ has an important influence on water supply, agricultural, and hydroelectric power generation. 
Over western South America, the Andes Mountains span the length of the west coast. The Andes separate dry conditions to the west and moist conditions to the east at tropical and subtropical latitudes. Orographic lifting of moist, easterly trade winds enhances precipitation on the east side of the mountains and suppresses it on the west. In the mid-latitudes, this pattern reverses with moist conditions to the west of the Andes and dry conditions to the east (Garreaud et al. 2009). High altitude ice caps reside on the Andes, and millions of people in these regions rely on fresh water that originates from the snowpack in these mountains for their water resources (Demaria et al. 2013; Zazulie et al. 2018). These ice caps are retreating due to temperature increases, resulting in changes in seasonal streamflow, affecting the water supply to support cites, hydropower generation, and agriculture. The Atacama Desert, the world's driest, nonpolar desert, resides on the western side of the Andes. The extreme aridity of this desert can be attributed to the mechanical subsidence from the Andes in the subtropics, the upwelling of cool water from the northward flowing Humboldt Current that causes a constant temperature inversion, and the strong subtropical Pacific anticyclone which enhances subsidence (Schulz et al. 2012). A combination of these mechanisms contribute to precipitation suppression, resulting in an average annual precipitation of about $1 \mathrm{~mm}$ in the northern region of the desert to $80 \mathrm{~mm}$ in the southern region (Schulz et al. 2012). With observed changes across all of South America, many of which have been attributed to human activity, it is of high importance to gain a firm and comprehensive understanding of expected future change.

\section{Previous Climate Model Research Over South America}


An important step in studying climate change in any region of the world is to understand how well climate models can simulate the observed climate. Climate modeling has matured in recent decades due to the expansion of Global Climate Models (GCMs) through the six phases of the Coupled Model Intercomparsion Project as models have become more advanced and more modeling groups around the world participate. These projects are developed by modeling centers around the world, and they allow scientists to investigate global projections of climate change (IPCC 2014). The most recent phase of these projects is the sixth phase, however, due to limited model availability, the fifth phase, otherwise known as the Coupled Intercomparsion Project Phase 5 (CMIP5) was used in this study. This phase was completed in 2013, and these models have been used for global climate studies thenceforward (Taylor et al. 2012). Towards the goal of evaluating the skill of state-of-the-art climate models over South America, Marengo et al. (2014) investigated numerous global climate models (GCMs) in CMIP5 to understand their ability to reproduce the current climate, to understand the reliability of future climate projections, and to assess how future climates will impact crops in South America. They found that past temperatures are reproduced well in the suite of climate models. However, representation of past precipitation patterns in climate models have large biases when compared to observations. This finding suggests that climate models' projections of future change in precipitation are not as reliable as temperature. Sierra et al. (2015) investigated how well precipitation was represented in northern South America in relationship to the Intertropical Convergence Zone (ITCZ) and low-level jets using seven different CMIP5 models. They found that models better 
represent precipitation patterns during the boreal summer and fall due to a better representation of the location of the ITCZ during these seasons. Conversely, models did not represent precipitation patterns well during boreal winter and spring because they cannot accurately represent the location of the ITCZ. Similarly, Yin et al. (2013) analyzed models in the CMIP5 suite to understand how well these models can simulate precipitation and their processes over tropical South America, specifically Amazonia, and found that most models underestimated precipitation in tropical South America. This can be attributed to an overestimation of surface net radiation (incoming shortwave radiation minus outgoing longwave radiation) in CMIP5 models, resulting in a high Bowen ratio and an underestimation of precipitation in models. In this study, models that better represented moisture convergence and surface evapotranspiration had more realistic rainfall climatologies. Likewise, Barros and Doyle (2018) found that CMIP5 models greatly underestimate warm season precipitation in southeastern South America. Since precipitation in this area is mostly dominated by the South American low-level jet that transports warm, moist air from the Amazon, they looked closely at low-level circulation in climate models to diagnose the issue. Consequently, they discovered that 17 out of the 18 models analyzed underestimate this northern flow that brings water vapor into southeastern South America. This underestimation in circulation is associated with the underestimation in precipitation.

Understanding which mechanisms need to be represented well to accurately produce precipitation sheds light on which mechanisms might also be important when investigating future climates. Towards this goal, Chen et al. (2018) studied the link 
between future drying in Northern South America represented in CMIP5 models and the Atlantic Meridional Overturning Circulation. They separated models into different groups based on their ability to accurately represent sea surface temperatures in the North Atlantic Ocean. They concluded that models that were able to accurately reproduce the warm North Atlantic sea surface temperatures for the present climate had a stronger and slower Atlantic meridional overturning circulation. These models projected a larger precipitation decrease by the year 2100 than the models that did not accurately represent North Atlantic sea surface temperatures.

To the knowledge of the author, there has not been any previous studies that performed a comprehensive assessment of future change in various climate variables over South America. Therefore, the goals of this study are to (1) assess projections of change in a set of key climate variables for the end of the $21^{\text {st }}$ century in CMIP5 climate models; (2) quantify model agreement and uncertainty in future projections between the models for each variable; and (3) integrate findings into a comprehensive picture of projected climate change over South America.

\section{Data}

Climate model data for this study are from the CMIP5 archive, and the models used in this study and their native resolution are found in Table 1. Data from the CMIP5 archive is freely available for download, and can be retrieved from the Program Climate Model Diagnosis and Intercomparision's (PCMDI) website: https://esgfnode.llnl.gov/search/cmip5/. Simulations from the CMIP5 archive are performed by different modeling agencies around the world, organized by the World Climate Research 
Programme's (WCRP) Working Group on Coupled Modelling (WGCM) (Yin et al. 2012). The purpose of CMIP5, and the prior phases, is to aid in the Assessment Reports written by the Intergovernmental Panel on Climate Change (IPCC). CMIP5 was used for the Fifth Assessment Report. The two experiments used from the CMIP5 model output were the historical and RCP8.5 experiments. The historical experiment is simulated using changes of atmospheric composition due to anthropogenic and volcanic influences, solar forcing, aerosol emissions and land use change (Taylor et al. 2012; Yin et al. 2012). RCP8.5 is the highest emissions scenario, also known as the "Business-as-Usual" scenario, forced by increasing greenhouse gas emissions with a radiative forcing of $8.5 \mathrm{~W}$ $\mathrm{m}^{-2}$ by the end of the $21^{\text {st }}$ century. This emission scenario was selected because it produces the largest signal, allowing for more statistically robust assessments of model agreement on future projections of the response of climate to increased radiative forcing.

All models with data for all variables available were analyzed resulting in a 27model suite. A set of seven climate variables were analyzed, chosen to represent a range of key dynamic and thermodynamic features that may be affected by a warming climate, and to provide a comprehensive picture of projected change and model agreement across the continent. These variables are precipitation, temperature, sea level pressure, evapotranspiration, zonal and meridional wind at 850,500 , and $250 \mathrm{hPa}$, and integrated water vapor transport. It is acknowledged that these variables are not an exhaustive list, but many key processes and impacts can be related to those chosen for analysis. 


\section{Methods}

The study region for this project encompasses the whole continent of South America and adjacent oceans, spanning from $-130^{\circ}$ to $-5^{\circ}$ west longitude and from $-75^{\circ}$ to $35^{\circ}$ north latitude. The decision to include data over the ocean, rather than looking solely at the continent, is to assist in understanding change in the large-scale circulation patterns that may affect South America. For model intercomparison, model data were first bilinearly interpolated to a common $2^{\circ} \times 2^{\circ}$ grid. For this study, the historical period is defined from 1961 to 1990, and the future period is 2071 to 2100. Each model's output was then divided into separate meteorological seasons defined as December, January, February (DJF); March, April, May (MAM); June, July, August (JJA); September, October, November (SON). The 30-year seasonal averages for the historical and RCP8.5 outputs were subtracted from each season to calculate the seasonal projected change for the end of the $21^{\text {st }}$ century. A student's t-test was performed on each seasonal variable change for each model to identify grid points with a change signal that is significant at the $95 \%$ confidence level relative to the historical simulation period.

To assess model agreement on sign and significance of change, the number of models that agreed on significant negative or positive changes was counted, and grid cells where more than half of the models agreed on significant positive or negative changes were included. The number of models that agreed on non-significant changes in each variable was also counted. This identifies the areas where models agree, but do not fall into the category of significant positive or negative changes. Categorizing significant and non-significant changes clearly highlights where the model projections are not in 
agreement. This methodology cannot be used to analyze model agreement for temperature because it is projected to significantly increase everywhere. Therefore, model agreement for future temperature projections was analyzed by calculating the standard deviation of all 27 model projections at each grid cell.

\section{Results}

\section{Temperature}

The CMIP5 multi-model ensemble mean projection of temperature shows warming across all of South America by the end of the $21^{\text {st }}$ century for all seasons, with the greatest magnitude of warming projected over the tropics in SON (Figure 1d). All individual models also show statistically significant warming over most of South America (not shown), but of varying magnitudes. Furthermore, regions of relatively large magnitude warming also tend to exhibit the largest magnitude of intra-ensemble model spread, as highlighted by the relatively large standard deviation contours in Figure 1. Grid cells with relatively larger standard deviations reveal the areas that have larger variability in model projections of the magnitude of temperature change, introducing more uncertainty in the multi-model ensemble of this change. However, grid cells with relatively small standard deviations represent areas where there are more constrained model projections of temperature change, suggesting a higher ensemble consensus. For example, in northern Brazil in DJF, the multi-model ensemble projects an increase in temperature of about $4.5^{\circ} \mathrm{C}$ by the end of the $21^{\text {st }}$ century relative to the $1961-1990$ base period, but with a standard deviation of the 27 model mean temperature projection of $1.5^{\circ} \mathrm{C}$. This relatively large standard deviation stems from MIROC5, the model 
simulating the least warming, projecting an increase of $2.3^{\circ} \mathrm{C}$ and ACCESS1.3, the model simulating the most warming, projecting an increase of $8^{\circ} \mathrm{C}$. Similarly, over northern Bolivia in SON, the multi-model ensemble projects a warming of about $5.5^{\circ} \mathrm{C}$ with a standard deviation of $1.7^{\circ} \mathrm{C}$. In this location, GISS-E2-H, the model with the least warming, projects an increase of $2.2^{\circ} \mathrm{C}$, and GFDL-CM3, the model with the most warming, projects an increase of $9^{\circ} \mathrm{C}$. This large spread in values introduces considerable uncertainty in the projection of warming magnitude, with potentially impactful implications for society and the environment depending on which end of the spread is ultimately most realistic for the given radiative forcing. However, overall tropical South America is projected to experience the greatest warming magnitude in all seasons, but with the greatest magnitude in model spread, while southern South America is projected to warm by a relatively modest amount, consistent with Marengo et al. (2009).

\section{Precipitation}

Figure 2 shows the multi-model ensemble mean projection of precipitation change computed as a percent difference relative to the historical period (panels a-d) along with a quantification of model agreement (panels e-h). The multi-model mean generally projects a decrease in precipitation over most of western Patagonia in all seasons, and eastern tropical South America during JJA and SON. Increases are shown over La Plata Basin, especially in DJF and MAM, as well as the along the west coast of Colombia, Ecuador, and Peru in all seasons except SON.

To assess model agreement on sign and significance of projected change, the number of models that agree on a statistically significant change of the same sign are 
quantified in panels e-h of Figure 2. Grid cells shaded in yellow and red indicate where at least half of the 27 CMIP5 models agree on a statistically significant decrease in precipitation, while green and blue grid cells are where at least half show a significant increase. Gray shading indicates where at least half of the models show no significant change.

The multi-model mean drying signal over western Patagonia is projected to be statistically significant by most models, with especially strong agreement in DJF. The exact latitude of the decrease in precipitation in western Patagonia depends on the specific season, with the decrease in DJF expanding more southerly than the other seasons. South of this mean decrease in precipitation in JJA and SON, more than half of the models agree on significant increases in precipitation for the southernmost tip of South America. This region receives the bulk of its precipitation from stratiform clouds that form along frontal boundaries associated with mid-latitude cyclones (Garreaud 2009). Mid-latitude cyclones travel along the mean position of the upper-level jet stream, which is also known as the extra-tropical storm track. As a result, the areas impacted by this mid-latitude precipitation reside between 30 and $50^{\circ} \mathrm{S}$. This western Patagonia decrease and southernmost tip of South America increase suggests a poleward shift in mean precipitation for this region by the end of the $21^{\text {st }}$ century. This is further supported by the high degree of model agreement on precipitation increases over the Pacific and Atlantic Oceans just north of the Antarctic Coast. Previous studies have found similar results when investigating projected changes in rainfall in midwestern Patagonia (Vera et al. 2006; Vicuña et al. 2010; Demaria et al. 2013; Zazulie et al. 2018). 
In southeastern South America (SESA), there is a projected increase in precipitation which is most notable in DJF, MAM and to a lesser degree, SON. The SACZ resides northeast of this area of increasing precipitation in central-eastern and southeastern Brazil. The SACZ is observed year-round, but it reaches maximum intensity during DJF when it is connected to an enhanced area of convection over the central part of the continent (Garreaud 2009). In DJF, this increase in precipitation resides on the poleward side of the SACZ, suggesting an increase in precipitation on the poleward side, consistent with trends observed in Zilli et al. (2019). Precipitation in SESA is also influenced from moisture in the Amazon basin that is transported by the South American low-level jet (Marengo et al. 2002; Junquas et al. 2012, Zanin and Satyamurty 2020). Previous studies suggest that this increase in rainfall is due to the intensification of the Chaco Low, the South American low-level jet and the poleward shift of the South Atlantic Subtropical Anticyclone, resulting in an increase in moisture being transported from Amazonia into SESA (Cabré et al. 2016).

Most models also agree on a significant increase in precipitation along the northern west coast of South America in parts of Colombia, Ecuador, and Peru in DJF and MAM, and a portion of Colombia in JJA. On the western side of the Andes Mountains, the increase in precipitation in this region appears to be the result of the systematic increase in precipitation in the Intertropical Convergence Zone (ITCZ). For the eastern side of the Andes Mountains, Marengo et al. (2012) concluded that this increase in precipitation in this region is due to a more intense inland penetration of the 
trade winds because of sea level pressure reductions (see Figure 3), resulting in enhanced orographic precipitation.

In SON, there is a robust decrease in the mean precipitation in Amazonia and northeast Brazil with over 20 models agreeing on a significant decrease. September through November in Amazonia is the transitional season between the dry (June August) and wet (December - February) season, and the projected decrease in precipitation during this period suggests an extended and drier dry season. This agrees with Boisier et al. (2015), where they found an expansion in the length of the dry season over southern Amazonia. However, they also found that CMIP5 models greatly underestimated precipitation in past climates, suggesting an underestimation for future drying in SON. Fu et al. (2013) found a significant increase in the length of the dryseason in observations since 1979 which may be attributed to the delay of dry season end date. Other previous studies suggest that this change is due to a poleward shift of the subtropical jet and an increase of local convective inhibition energy (Fu et al. 2013; Collow et al. 2016). A longer dry season corresponds to a prolonged fire season and it could contribute to a transition from a rainforest to a savanna regime in this region $(\mathrm{Fu}$ et al. 2013).

While there are regions where models agree on significant changes and on sign of change, many models for the continent, especially in DJF, JJA, and MAM, project nonsignificant changes. In Figure 2, gray areas indicate where more than half of the CMIP5 models agree on non-significant changes. This identifies the areas where models agree, but do not fall into the category of significant positive or negative changes since they are 
non-significant. Areas in white, such as over Northeast Brazil in DJF and over northern South America in SON, are where there is a lack of model consensus on sign and significance of changes in precipitation. When comparing these areas of model disagreement to the figures of the multi-model ensemble, they correspond to areas where the projected changes are close to zero. Although the multi-model ensemble projects no changes in these areas, especially in tropical South America, it does not necessarily mean that there will not be any changes in precipitation by the end of the $21^{\text {st }}$ century. Rather, there is too much uncertainty in the models to make confident conclusions about the future change in precipitation.

\section{Sea Level Pressure}

Investigating seasonal projected changes in sea level pressure, especially regions that are dominated by semi-permanent highs and lows, is important because the path that weather systems take is highly dependent on the location of these semi-permanent pressure systems. Changes in sea level pressure can also help diagnose changes in other quantities such as precipitation. Figure 3 shows mean change in sea level pressure (panels a-d) and model agreement on projected change (panels e-h) in the same format as Figure 2. Generally, the CMIP5 ensemble mean shows an increase in sea level pressure over the South Pacific and South Atlantic sub- and extra-tropics, as well as over much of Patagonia in all seasons. This band of increase is north of a band of projected decreasing sea level pressure, indicating a poleward shift of the mid-latitude storm track and a poleward expansion of the subtropical high-pressure belt (Seidel et al. 2008). This projected change in pressure is also consistent with the projected change in precipitation 
shown in Figure 2, as the extra-tropical storm track shifts poleward with global warming (Yin 2005; Bengtsson et al. 2006). Additionally, a decrease in sea level pressure is broadly projected over tropical South America.

Most models agree on the decrease in sea level pressure in all seasons over southern South America (panels e-h). However, model agreement is much higher in DJF than all other seasons with nearly all models projecting a significant decrease, with the lowest level of agreement in SON. This corresponds to the most robust projected decrease in precipitation also in DJF, linking the decrease in sea level pressure with a poleward shift of the extra-tropical storm track in the summer season. The more modest level of agreement in $\mathrm{SON}$ is also supported by the more modest area and level of agreement in precipitation change in this region. Models are in generally strong agreement that no significant change in sea level pressure is projected over the very southern tip of South America in JJA and SON, however a majority of models do project an increase in precipitation in this region for these seasons. This may be a thermodynamic response to a warmer atmosphere where precipitation increases without a significant change in storm track intensity or location.

In tropical South America, more than half of CMIP5 models project significant decreases in sea level pressure, with this projection the most widespread and with the largest agreement in SON and most confined with least agreement in DJF. The large area of strong model agreement in a decrease in sea level pressure in SON corresponds to the highest magnitude in warming between all four seasons (Figure 1d), and a significant decrease in precipitation (Figure $2 \mathrm{~h}$ ). Together these results support the hypothesis that 
these changes result from decreased cloudiness in Amazonia by the end of the $21^{\text {st }}$ century. Decreased cloudiness would allow more incoming solar radiation to reach the surface, increasing temperatures. Greater warming would support more unstable airmasses and decreases in pressure due to the formation of a surface thermal low in these areas. However, a decrease in pressure does not necessarily mean an increase in precipitation because previous studies have suggested an increase of convection inhibition in this area, which would inhibit cloud formation (Fu et al. 2013; Collow et al. 2016).

Integrated Water Vapor Transport

Investigating how integrated water vapor transport (IVT) is projected to change in the future on the seasonal scale allows for distinguishing how large-scale sources of moisture transport, such as storm-tracks and low-level jets are changing as a result of dynamic and thermodynamic changes. These features are driven by upper and lower level circulation and have significant influences on seasonal precipitation (Garreaud et al. 2009; Berman et al. 2012). Figure 4 (panels a-d) reveals a decrease in the multi-model mean of IVT over extra-tropical South America and northeastern South America and an increase over the northwestern coast and central South America. These changes are found to be statistically significant in most models. This decrease in IVT in the extra-tropics corresponds to the increase in sea level pressure and a decrease in precipitation, further highlighting the poleward shift in the extra-tropical storm track, and its associated moisture transport, that was discussed in previous sections. In northwestern and central South America, the increase in IVT corresponds to the areas in South America where 
precipitation is also projected to increase. The increases in IVT supports the claim that the precipitation increases over the northwestern coast of South America and over SESA are due to more moisture being funneled into these areas through an increase in the northeasterly trade winds and the South American low-level jet, respectively. For the north and northeastern regions of South America, there is not a strong consensus on how IVT is projected to change in the future, except over northeastern Brazil in SON and JJA where models agree on a significant decrease in IVT in this area.

\section{Evapotranspiration}

Figure 5 shows the multi-model ensemble mean projection of evapotranspiration in percent change (panels a-d) along with a quantification of model agreement (panels eh) as in Figures 2-4. The multi-model mean generally projects increases in evapotranspiration in many areas in South America, with some exceptions. Namely, decreases in evapotranspiration are projected over far northern South America in DJF, a small part of Amazonia in JJA, and a broader region over mostly Brazil in SON. The largest increases in evapotranspiration are projected over La Plata Basin and northwestern South America in all seasons and Patagonia in JJA. The multi-model ensemble increasing signal over northwestern South America is projected to be statistically significant by most models. This projected increase in evapotranspiration is thermodynamically consistent with physical expectations because warmer temperatures allow the atmosphere to store more water vapor, which as a result, increases potential evapotranspiration. However, over northeastern South America, models project 
statistically significant decreases in evapotranspiration for the end of the $21^{\text {st }}$ century, especially in SON.

Changes in evapotranspiration are influenced by and may also influence changes in other variables, such as precipitation and temperature. The most prominent example of this is in SON where the decrease in evapotranspiration is co-located with the maximum change in temperature, a significant decrease in precipitation, and a decrease in sea level pressure. Barkhordarian et. al (2019) found that there has been an increasing trend in vapor pressure deficit in recent years over tropical South America during dry months that is beyond the range of natural variability. Therefore, a combination of an increase in vapor pressure deficit, decreased precipitation, and increased incoming solar radiation all play an important role in the climate changes of this area. In regards to temperature, a mechanism that explains this relationship is that a decrease in evapotranspiration leads to an increase in sensible heat flux, resulting in an increase in air temperature (Seneviratne et al. 2010). This occurs because whenever soil moisture limits the total energy used by latent heat flux, more energy is available for sensible heating (Seneviratne et al. 2010). This creates a positive feedback loop where a decrease in soil moisture results in a decrease in evapotranspiration due to less available moisture to evaporate from the surface, therefore increasing surface air temperature. This increase in surface air temperature leads to a higher vapor pressure deficit and evaporation demand, increasing the potential evapotranspiration despite drier conditions, and further decreasing the soil moisture. This leads to a further increase in surface air temperature as the feedback loop 
keeps repeating itself. This relationship helps explain why there is a maximum in projected temperature over Brazil in SON.

However, the link between precipitation and evapotranspiration is less straight forward due to the number of processes involved in precipitation formation. This relationship also exists as a potentially positive or negative feedback loop. Intuitively, higher precipitation leads to higher soil moisture, resulting in a higher rate of evapotranspiration (Seneviratne et al. 2010), but whether a higher rate of evapotranspiration results in a higher precipitation is uncertain (Seneviratne et al. 2010; Findell et al. 2011). One uncertainty is because the rate of precipitation needs to be at least equivalent to the rate of evapotranspiration or else soil moisture decreases. In this scenario, a rate of precipitation that is lower than the rate of evapotranspirtation suggests a lower amount of available soil moisture, therefore, it is difficult to make assumptions about whether or not a higher rate of evapotranspiration suggests higher rates of precipitation because it is also dependent on the available soil moisture and other processes involved in precipitation formation. Many authors have identified a possible positive relationship between evapotranspiration and precipitation through modeling studies (Shukla and Mintz, 1982; Trenberth et al., 1988; Schär et al., 1999; Koster et al., 2000; Pal and Eltahir, 2008; Betts, 2004; Schubert et al., 2004; as cited in Seneviratne et al. 2010), however, results from observational studies that investigated the relationship between evapotranspiration and precipitation were inconclusive in determining the magnitude of the relationship due to indications of positive, negative, or no feedbacks. (Seneviratne et al. 2010). Therefore, the question on whether one causes the other 
remains unanswered. A careful water budget analysis in observations and the whole feedback loop would help answer this, but it is beyond the scope of this study.

\section{Zonal Winds}

Figures 6, 7, and 8 describe the multi-model ensemble changes and the model agreement in zonal winds at 850,500 , and $250 \mathrm{hPa}$. Panels a-d represent the multi-model ensemble for the mean seasonal zonal winds from 1961-1990 with orange shading depicting winds coming from the west and blue shading depicting winds coming from the east. The overlaying contours represent the overall change in zonal winds for the end of the $21^{\text {st }}$ century to differentiate directional changes. For example, in Figure 7 panels e-h, the magnitude of $500 \mathrm{hPa}$ zonal winds is projected to increase over northern South America, but the contours in this same region in Figure 7 panels a-d are negative. This is because this is an area characterized by easterly winds, therefore an increase in wind magnitude results in a negative overall change in the zonal wind value as the easterly winds become more easterly. Therefore, a positive overall change in zonal wind values in panels a-d for areas with dominant easterlies represent a decrease in the magnitude of the easterlies because the negative winds are becoming more positive, or more westerly. This would also be represented by a decrease in overall zonal wind magnitude in panels e-h. The opposite is true for areas with westerly dominated winds, as positive overall changes represent an increase in the magnitude of the westerlies and overall negative changes represent a decrease in the magnitude of the westerlies. Panels e-h represent model agreement on significant changes in the magnitude of zonal wind magnitude, regardless of directions for the end of the $21^{\text {st }}$ century, with yellow and orange shading representing 
a consensus on a significant increase in the magnitude of the zonal winds and blue and purple shading representing a consensus on a significant decrease in the magnitude of zonal winds, regardless of direction.

The most robust agreement in change for zonal winds is a projected increase in the multi-model ensemble for the southern boundary of the extra-tropical westerlies. This change is prominent at every pressure level and for all seasons. The magnitude of this multi-level, multi-seasonal increase is significant in most CMIP5 models with the most model agreement on significant increases being in DJF and MAM. The multi-model ensemble also projects a multi-level, multi-seasonal decrease in the northern boundary of the extra-tropical westerlies, but this decrease is only significant in more than half of the CMIP5 models for every pressure level in DJF. MAM and SON have this decrease in more than half of the CMIP5 models at $850 \mathrm{hPa}$ and $500 \mathrm{hPa}$, and JJA only has the decrease in more than half of the CMIP5 models at the $850 \mathrm{hPa}$ level. Nonetheless, these changes highlight the poleward migration in the South Pacific and South Atlantic anticyclones, with winds that follow a counter-clockwise path around the center of the highs, and the extra-tropical storm track. As these features move poleward, the anticyclonically rotating wind field associated with their boundaries also move poleward, resulting in a decrease in the magnitude of the westerlies northward and an increase in the magnitude of the westerlies southward.

At the 500 and $250 \mathrm{hPa}$ pressure levels, the multi-model ensemble projects an increase in the subtropical westerlies and this increase is found to be significant in almost all CMIP5 models. The subtropical jet stream is located at the poleward boundary of the 
Hadley Circulation; therefore, this highlights the expansion of the tropical belt as the subtropical boundaries of the Hadley Circulation migrate poleward (Seidel et al. 2008). At the $500 \mathrm{hPa}$ pressure level, the multi-model ensemble projects an increase in the tropical easterly winds over northern South America. This increase is found to be significant in most models for all seasons. This supports the precipitation increase in all seasons, except SON, for the northwestern coast of South America which is a result of there being a more intense inland penetration of the easterly trade winds to transport more moisture from the Atlantic Ocean and Amazon towards this region. However, although SON is projected to have a significant increase in the easterlies, it does not see a significant increase in precipitation for the northwestern coast as in other seasons.

\section{Meridional Winds}

Figures 9, 10, and 11 describe the changes and the model agreement in meridional winds at 850,500 , and $250 \mathrm{hPa}$. The methodology for this analysis is the same as Figures 6, 7, and 8, but for Figures 9, 10, and 11 panels a-d, orange shading represents winds coming from the south and blue shading represents winds coming from the north. At the $850 \mathrm{hPa}$ pressure level, the multi-model ensemble projects an increase in magnitude of the northerly winds in northern and central South America in DJF and SON. There is a strong consensus that these northerly winds are going to significantly increase by the end of the $21^{\text {st }}$ century. However, in JJA at $850 \mathrm{hPa}$, the multi-model ensemble projects a decrease in the southerly winds in northern South America. Unlike DJF and SON, the meridional winds in JJA are climatological southerly, therefore the southerly winds are becoming weaker, whereas in DJF and SON the northerly winds are becoming stronger. 
There is strong model consensus that the decrease in the southerly winds in JJA will be significant. At the $500 \mathrm{hPa}$ level, DJF does not show strong model consensus on significant or non-significant changes, but JJA and MAM do have strong consensus that meridional winds at $500 \mathrm{hPa}$ will not significantly change. However, in SON, the multimodel ensemble projects an increase in the southerly winds over central west coast and adjacent interior of South America that is found to be significant in more than half of CMIP5 models. At $250 \mathrm{hPa}$, the multi-model ensemble projects a decrease in the magnitude of the northerly winds along the northwest coast of South America in all seasons. The ensemble also projects that there will be an increase in the northerly wind over central Patagonia in SON and an increase in the southerly winds over northern South America in DJF. More than half of the CMIP5 models agree on significant changes in the northerly winds over the northwestern coast, but the strongest model agreement on the decrease is in JJA and SON. In SON, there is also strong model agreement in the increase of the northerly winds over central Patagonia, and in DJF, there is strong model consensus on the increase in the southerly winds over northern South America.

\section{Summary and Conclusion}

In this study, model agreement in projected change across 27 different CMIP5 climate models for temperature, precipitation, sea level pressure, evapotranspiration, integrated water vapor transport, zonal winds, and meridional winds was quantified over South America for the end of the $21^{\text {st }}$ century. To summarize this multi-variate assessment, Figure 12 highlights the main conclusions for each season. In all seasons, statistically significant warming is projected for the entire continent, with the largest 
magnitude of warming in the tropics, especially in SON (Figure 1d), and the smallest magnitude of warming in Patagonia. However, tropical South America has the largest spread in the projected magnitude of warming and southern South America has the lowest. Furthermore, in all seasons, models agree on a significant decrease in precipitation in western Patagonia. This significant decrease in precipitation in western Patagonia stems from a poleward expansion of the subtropical anticyclone which also shifts the extra-tropical storm track poleward. This is shown in an increase in sea level pressure (Figure 3) and a decrease in integrated water vapor transport (Figure 4) in this same region. The exact location of significant precipitation decreases depends on latitude and poleward extent of the mechanisms driving this change. For example, in DJF, the increase in sea level pressure and decrease in IVT extends more southerly than the other seasons, allowing the decrease in precipitation to extend more poleward. Since the mechanisms driving this decrease in precipitation do not extend as far south in JJA and SON, models agree on a significant increase in precipitation in the southernmost tip of South America.

In DJF and MAM, models agree on a significant increase in precipitation in the northern west coast and southeastern South America. These changes can likely be attributed, at least in part, to an increase in moisture being transported to these regions via the northeasterly trade winds and the South American low-level jet. Additionally, models agree on significant decreases in precipitation along the northern coast of South America in DJF and JJA, and for most of northeastern South America in SON. The decrease in precipitation for northeastern South America coincides with the largest projected 
magnitude in warming, where models agree on a significant decrease in evapotranspiration (Figure 5h), and where the most models agree on a significant decrease in sea level pressure (Figure $3 \mathrm{~h}$ ). The combination of these changes suggests the contribution to a decrease in cloudiness during SON, which would prohibit precipitation, increase temperatures, dry out soil leading to less evapotranspiration, and decreasing sea level pressure.

Results from this study improve the understanding of future change of important climate variables while informing on the level of confidence that should be placed on the projection at regional and seasonal scales. Furthermore, this comprehensive assessment provides a general overview of future changes in synoptic level climatology that may be used as a resource for similar studies. For example, when there is a consensus between climate models on a specific change in a variable, such as the decrease in precipitation in western Patagonia in all seasons, or the decrease in precipitation over Brazil in SON, there is more confidence in these projections compared to areas where model projections vary. Addressing and understanding the uncertainty associated with these climate model projections can provide confidence on the usefulness of GCMs to other researchers for specific regions of South America. Outside of the scientific community, regions where there is more confidence on the model projects provides the people impacted by these changes a head start on what to expect by the end of the $21^{\text {st }}$ century, whereas in regions where there is a lack of confidence, work still needs to be done to fully understand what will occur in the future. Further research is recommended to expand this project for the 
sixth phase of the CMIP projects in order to assess whether or not the uncertainties associated with CMIP5 remain the same or change with the new suite of models. 


\section{Figures}

\begin{tabular}{llll}
\hline Model & Resolution & Model & Resolution \\
ACCESS1.0 & $1.25^{\circ} \times 1.88^{\circ}$ & HadGEM2-CC & $1.25^{\circ} \times 1.88^{\circ}$ \\
ACCESS1.3 & $1.25^{\circ} \times 1.88^{\circ}$ & HadGEM2-ES & $1.25^{\circ} \times 1.88^{\circ}$ \\
CanESM2 & $2.79^{\circ} \times 2.81^{\circ}$ & INMCM4 & $1.50^{\circ} \times 2.00^{\circ}$ \\
CMCC-CESM & $3.44^{\circ} \times 3.75^{\circ}$ & IPSL-CM5A-LR & $1.89^{\circ} \times 3.75^{\circ}$ \\
CMCC-CM & $0.75^{\circ} \times 0.75^{\circ}$ & IPSL-CM5A-MR & $1.27^{\circ} \times 2.50^{\circ}$ \\
CNRM-CM5 & $1.40^{\circ} \times 1.40^{\circ}$ & IPSL-CM5B-LR & $1.89^{\circ} \times 3.75^{\circ}$ \\
CSIRO-Mk3.6.0 & $1.87^{\circ} \times 1.88^{\circ}$ & MIROC-ESM & $2.79^{\circ} \times 2.81^{\circ}$ \\
GFDL-CM3 & $2.00^{\circ} \times 2.50^{\circ}$ & MIROC-ESM-CHEM & $2.79^{\circ} \times 2.81^{\circ}$ \\
GFDL-ESM2M & $2.02^{\circ} \times 2.50^{\circ}$ & MIROC5 & $1.40^{\circ} \times 1.41^{\circ}$ \\
GFDL-ESM2G & $2.02^{\circ} \times 2.00^{\circ}$ & MPI-ESM-LR & $1.87^{\circ} \times 1.88^{\circ}$ \\
GISS-E2-H & $2.00^{\circ} \times 2.50^{\circ}$ & MPI-ESM-MR & $1.87^{\circ} \times 1.88^{\circ}$ \\
GISS-E2-H-CC & $2.00^{\circ} \times 2.50^{\circ}$ & MRI-CGCM3 & $1.12^{\circ} \times 1.13^{\circ}$ \\
GISS-E2-R & $2.00^{\circ} \times 2.50^{\circ}$ & MRI-ESM1 & $1.12^{\circ} \times 1.13^{\circ}$ \\
GISS-E2-R-CC & $2.00^{\circ} \times 2.50^{\circ}$ & & \\
\hline
\end{tabular}

Table 1: CMIP5 models and their native resolution. Variables that were extracted from these models were precipitation, temperature, evapotranspiration, meridional winds, zonal winds, specific humidity, and sea level pressure. 

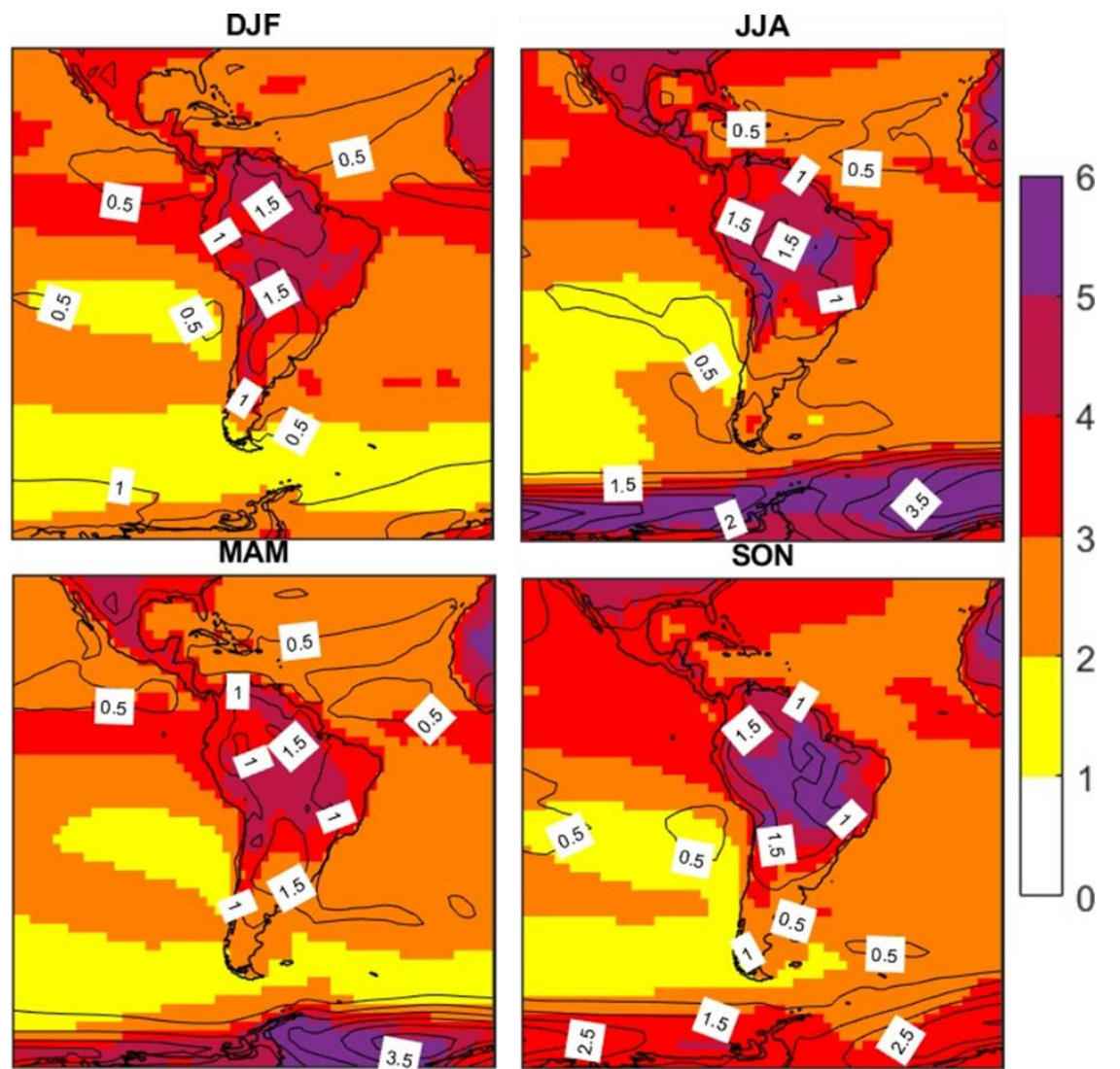

Figure 1: Shading represents the multi-model ensemble of the projected temperature

change in degrees Celsius for the end of the 21 st century. Contours represent the standard deviation of the projected temperature change for all 27 model projections. 

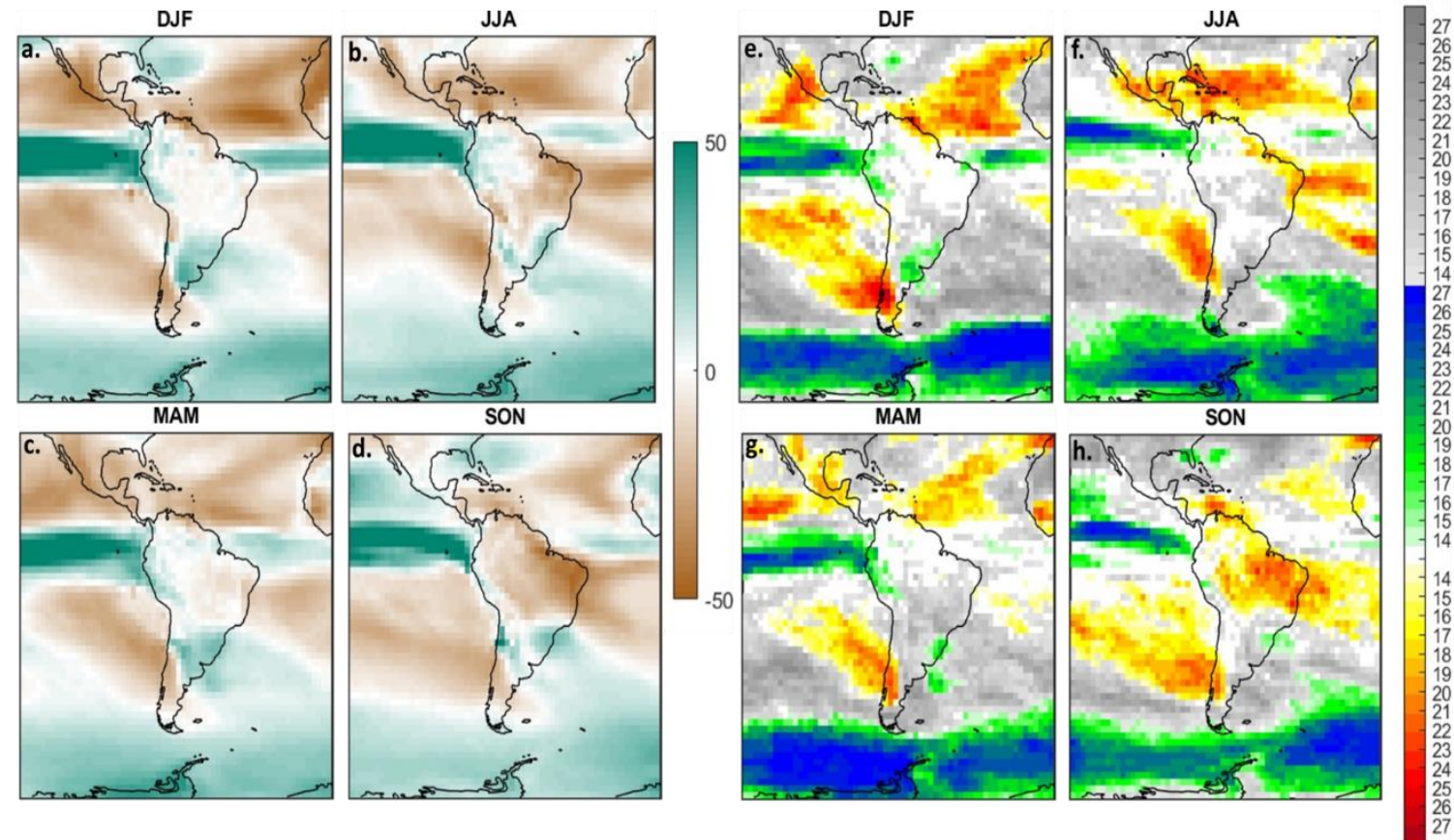

Figure 2: Panels a-d represent the change in the multi-model ensemble of precipitation in percent change for the end of the 21 st century. Panels e-h represent the number of models that agree on significant increases in precipitation (yellow-orange), significant decreases in precipitation (blue-purple), and non-significant changes (gray) for the end of the 21 st century. 

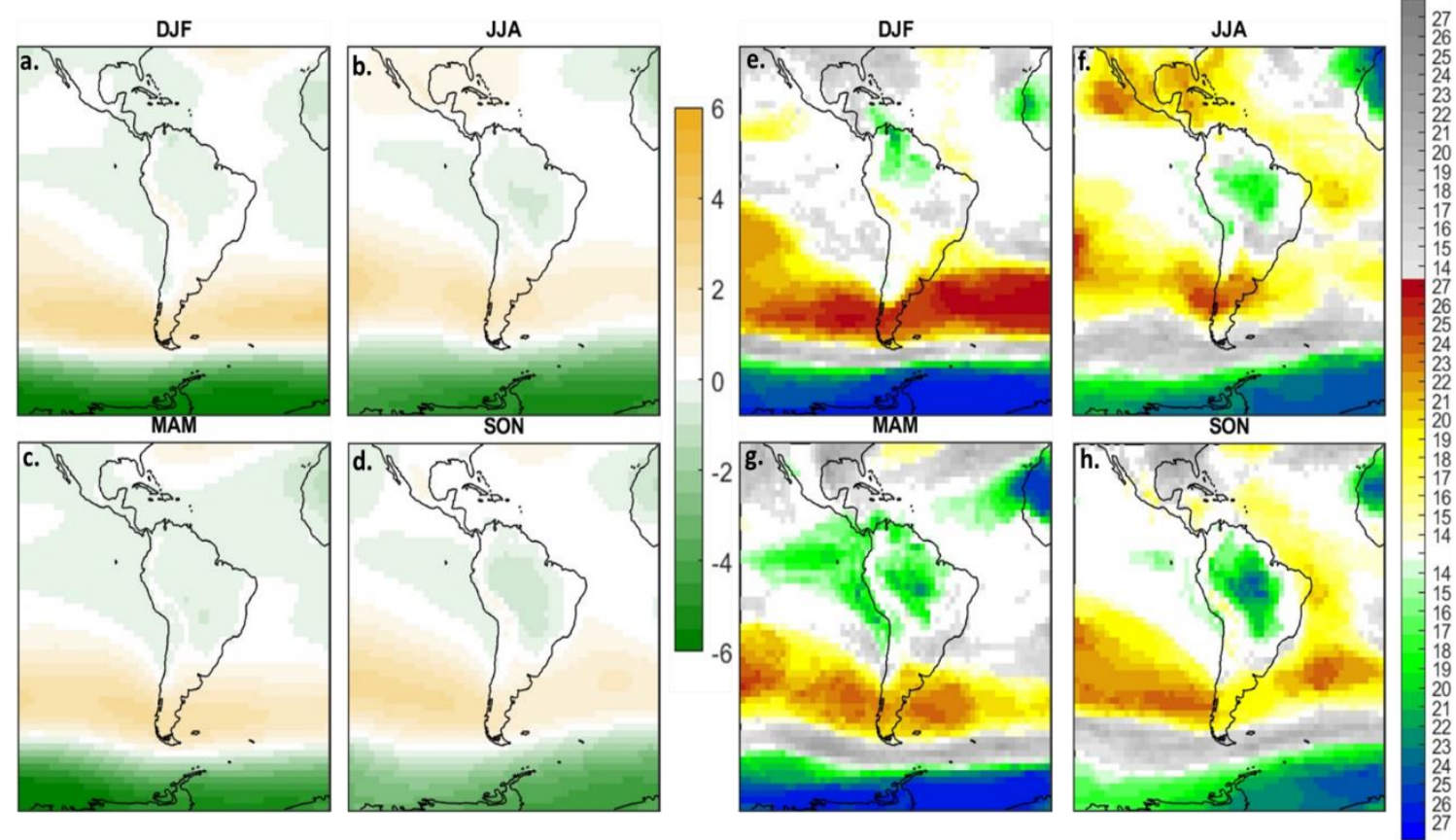

Figure 3: Panels a-d represent the change in the multi-model ensemble of sea level pressure in $\mathrm{hPa}$ for the end of the 21 st century. Panels e-h represent the number of models that agree on significant increases in sea level pressure (yellow-orange), significant decreases in sea level pressure (blue-purple), and non-significant changes (gray) for the end of the 21 st century. 

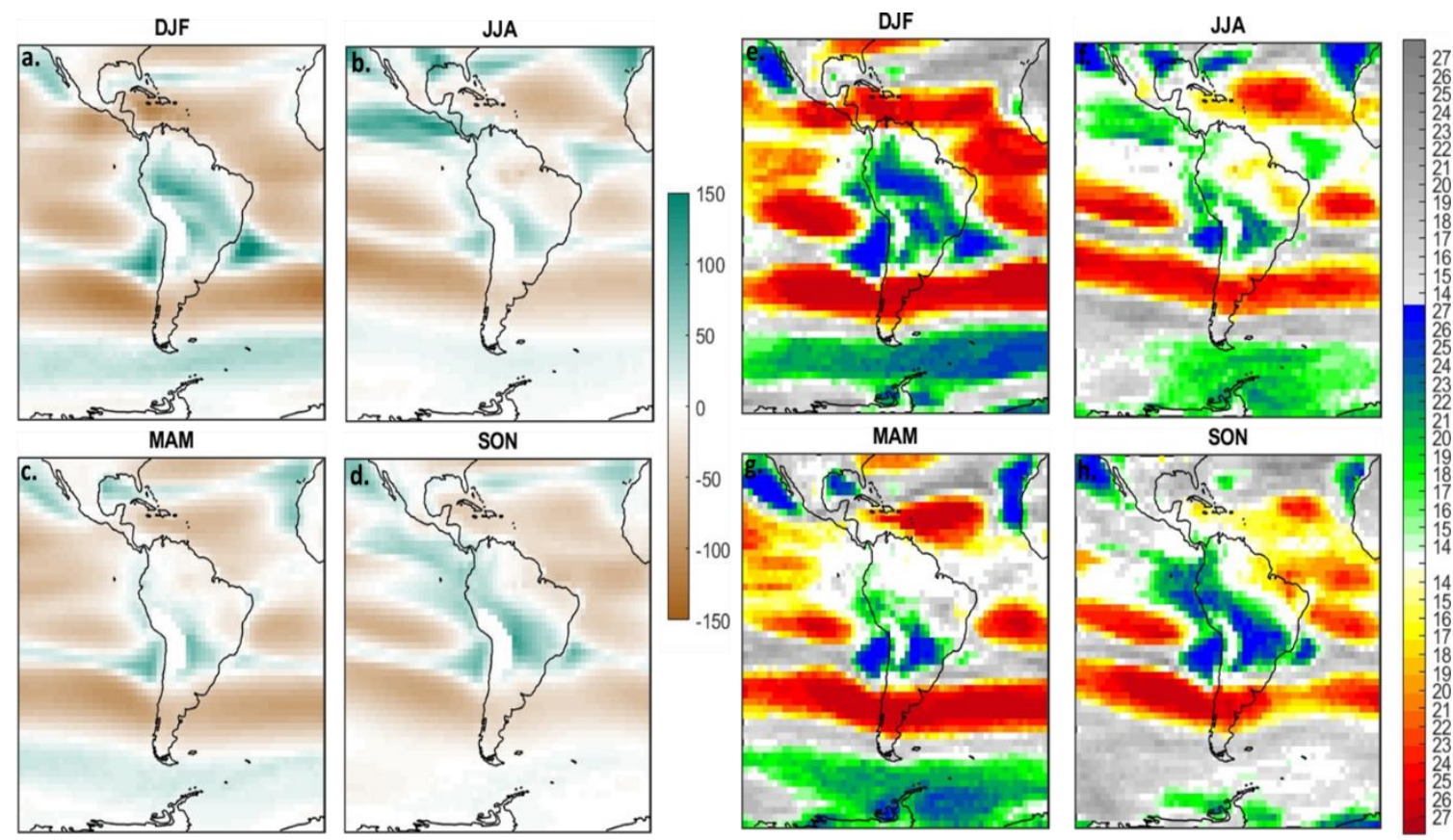

Figure 4: Panels a-d represent the change in the multi-model ensemble of IVT in $\mathrm{kg} \cdot \mathrm{m}^{-}$ ${ }^{1} \cdot \mathrm{s}^{-1}$ for the end of the 21 st century. Panels e-h represent the number of models that agree on significant increases in IVT (yellow-orange), significant decreases in IVT (bluepurple), and non-significant changes (gray) for the end of the 21st century. 

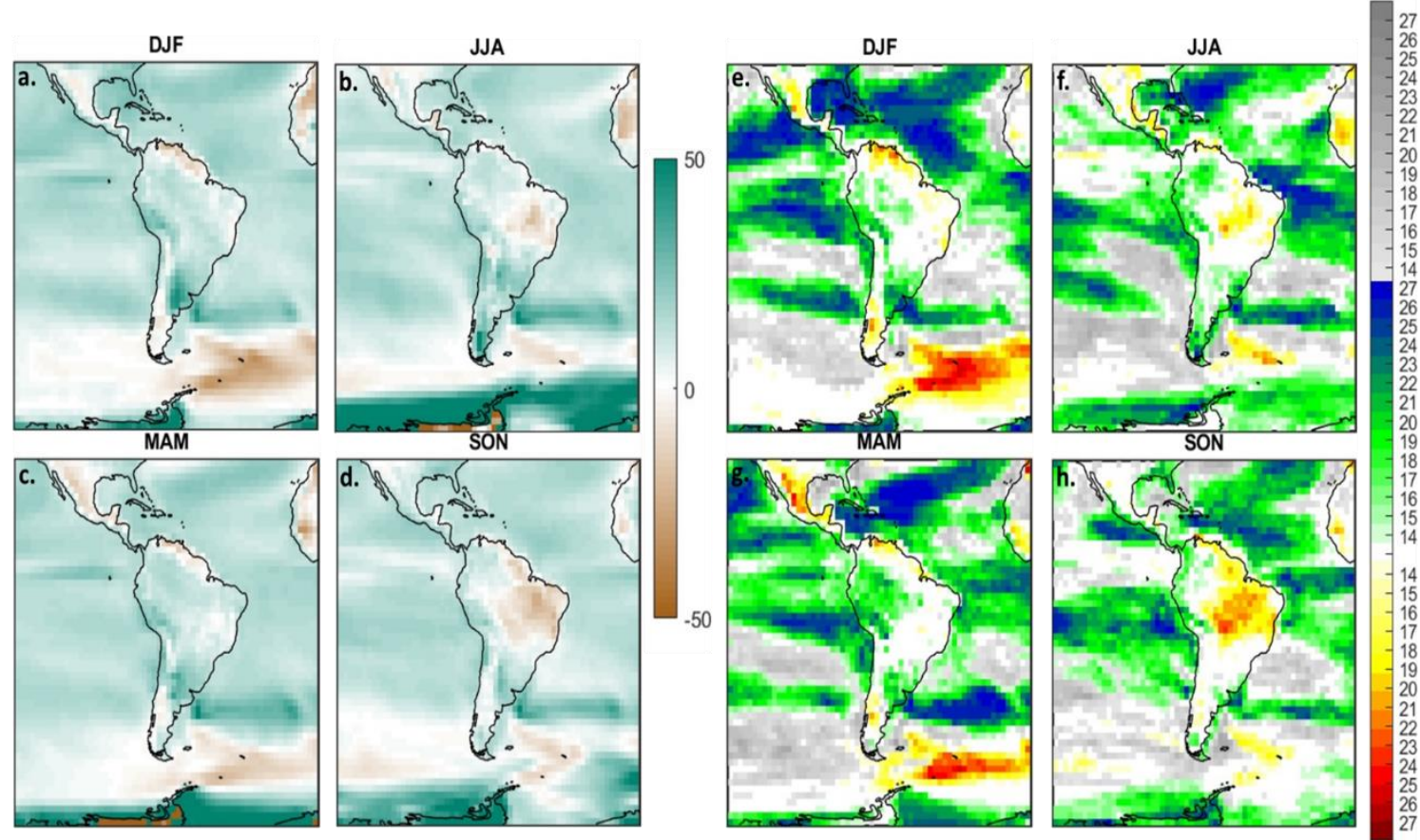

Figure 5: Panels a-d represent the change in the multi-model ensemble of

evapotranspiration in percent change for the end of the 21 st century. Panels e-h represent the number of models that agree on significant increases in evapotranspiration (greenblue), significant decreases in evapotranspiration (yellow-red), and non-significant changes (gray) for the end of the 21 st century. 

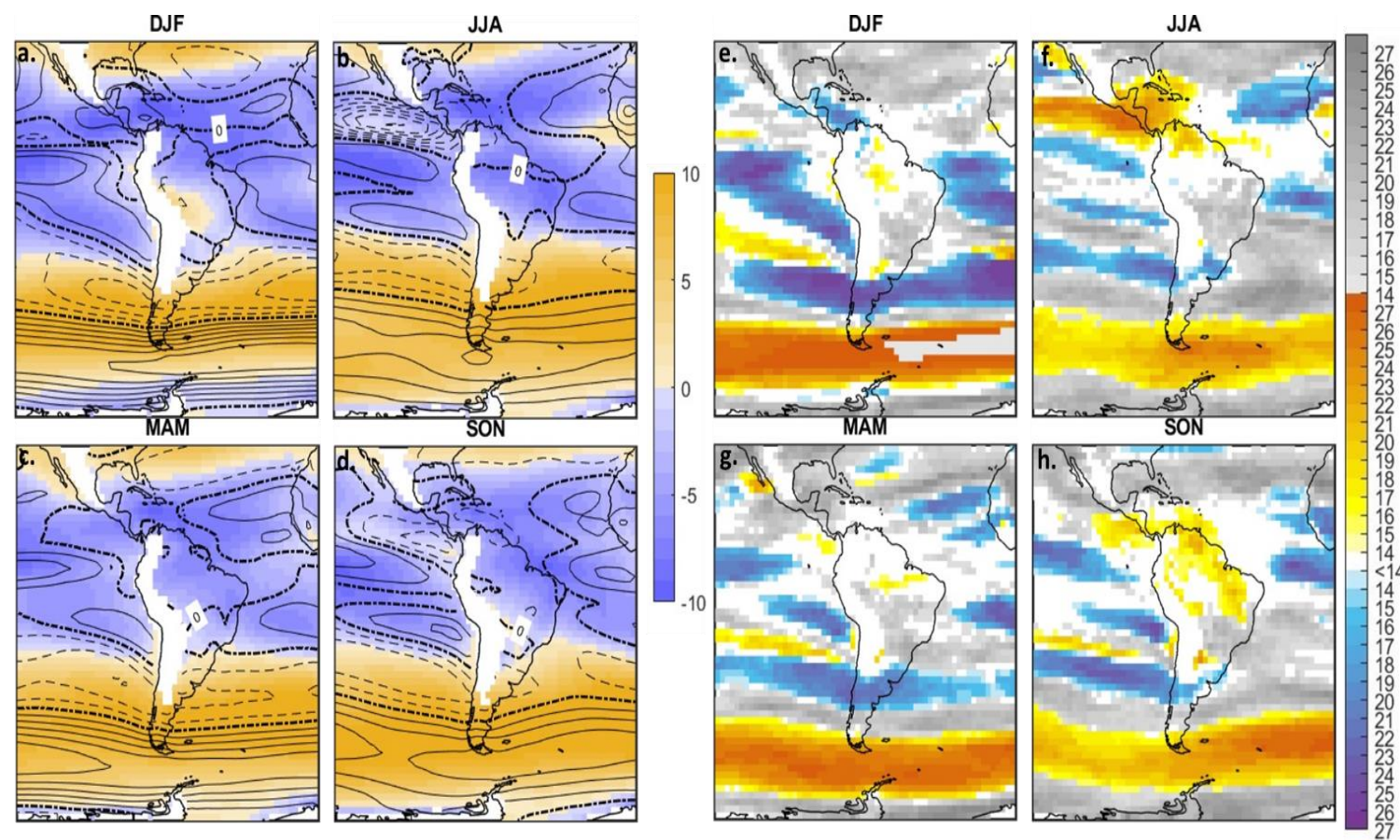

Figure 6: Panels a-d represent historical 850hPa zonal wind for 1961-1990 (shaded; m/s)

and overall change in 850 zonal wind for 2071-2100 using a 1961-1990 climatology

(contours). Contours are in increments of $0.5 \mathrm{~m} / \mathrm{s}$, and solid contours represent positive

changes and dashed contours represent negative changes. Panels e-h represent the number of models that agree on significant increases in the magnitude of the $850 \mathrm{hPa}$ zonal wind (yellow-orange), significant decreases in $850 \mathrm{hPa}$ zonal wind (blue), and non-significant changes (gray). Values are calculated in absolute change $(\mathrm{m} / \mathrm{s})$. 

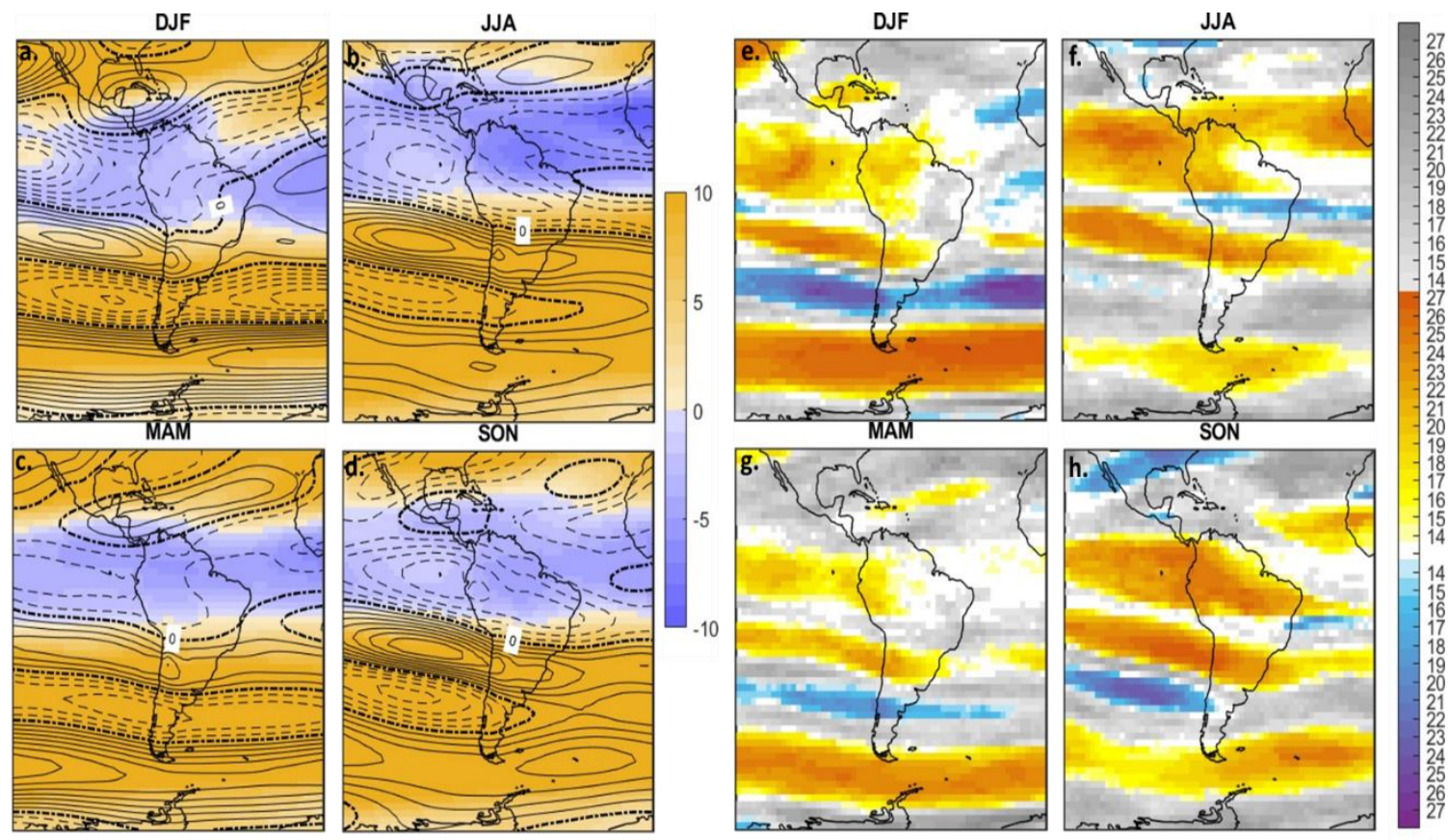

Figure 7: Same as Figure 6 but for $500 \mathrm{hPa}$ zonal wind. 

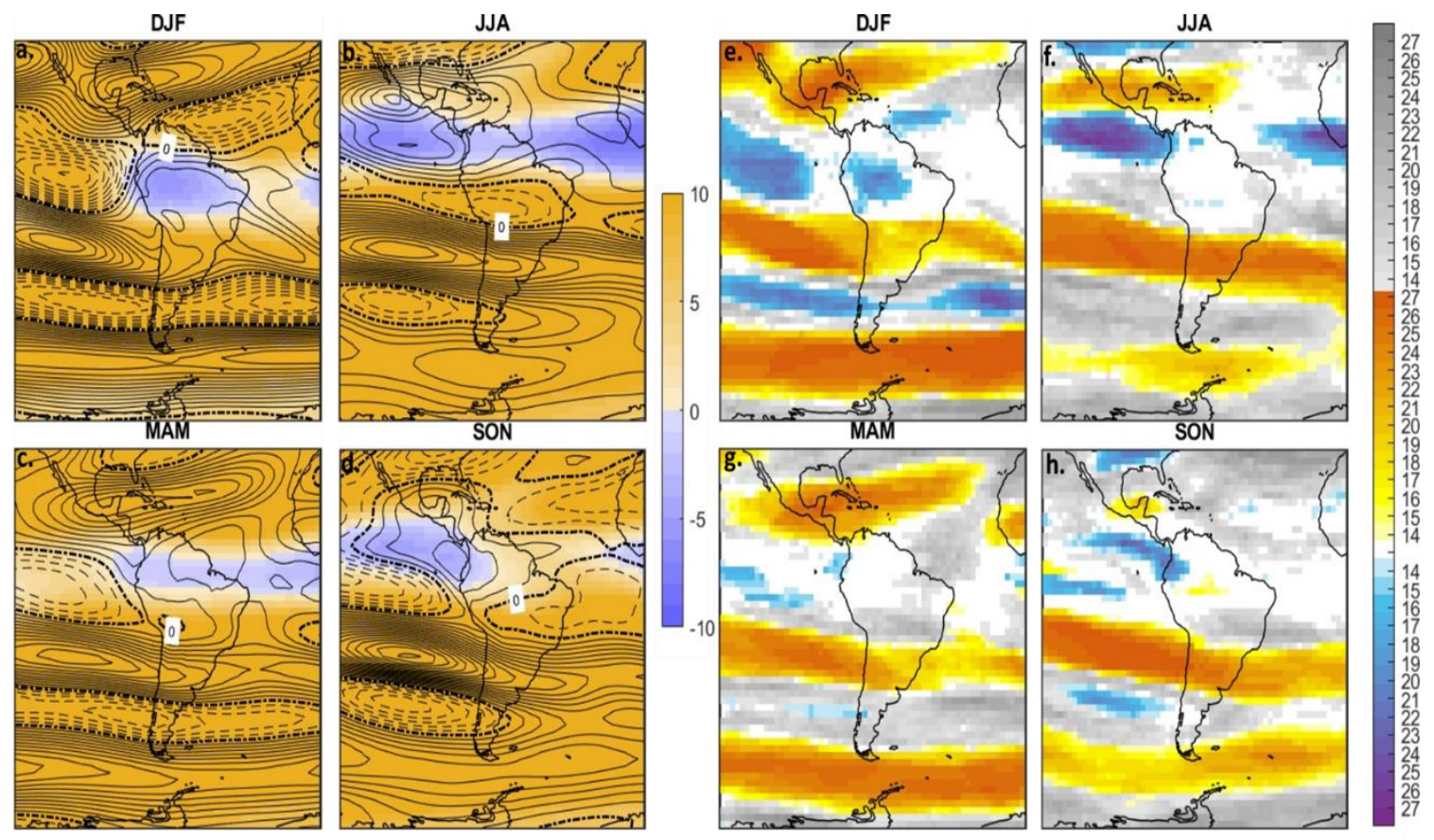

Figure 8: Same as Figure 6 but for $250 \mathrm{hPa}$ zonal wind. 

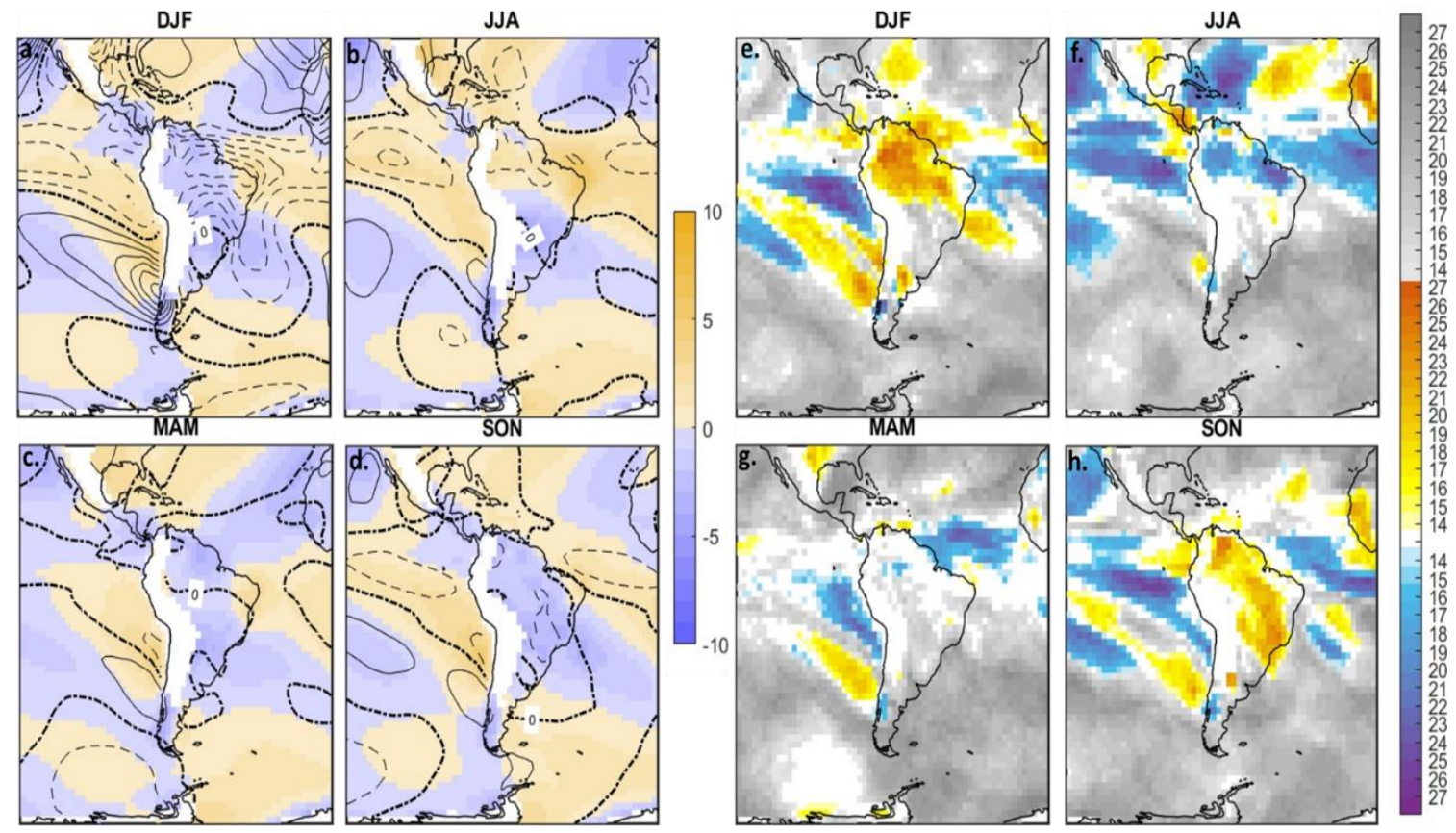

Figure 9: Figures a-d represent historical 850hPa zonal wind for 1961-1990 (shaded; m/s)

and overall change in 850 meridional wind for 2071-2100 using a 1961-1990 climatology

(contours). Contours are in increments of $0.5 \mathrm{~m} / \mathrm{s}$, and solid contours represent positive

changes and dashed contours represent negative changes. Figures e-h represent the

number of models that agree on significant increases in the magnitude $850 \mathrm{hPa}$ meridional wind (yellow-orange), significant decreases in $850 \mathrm{hPa}$ meridional wind (blue), and nonsignificant changes (gray). Values are calculated in absolute change $(\mathrm{m} / \mathrm{s})$. 

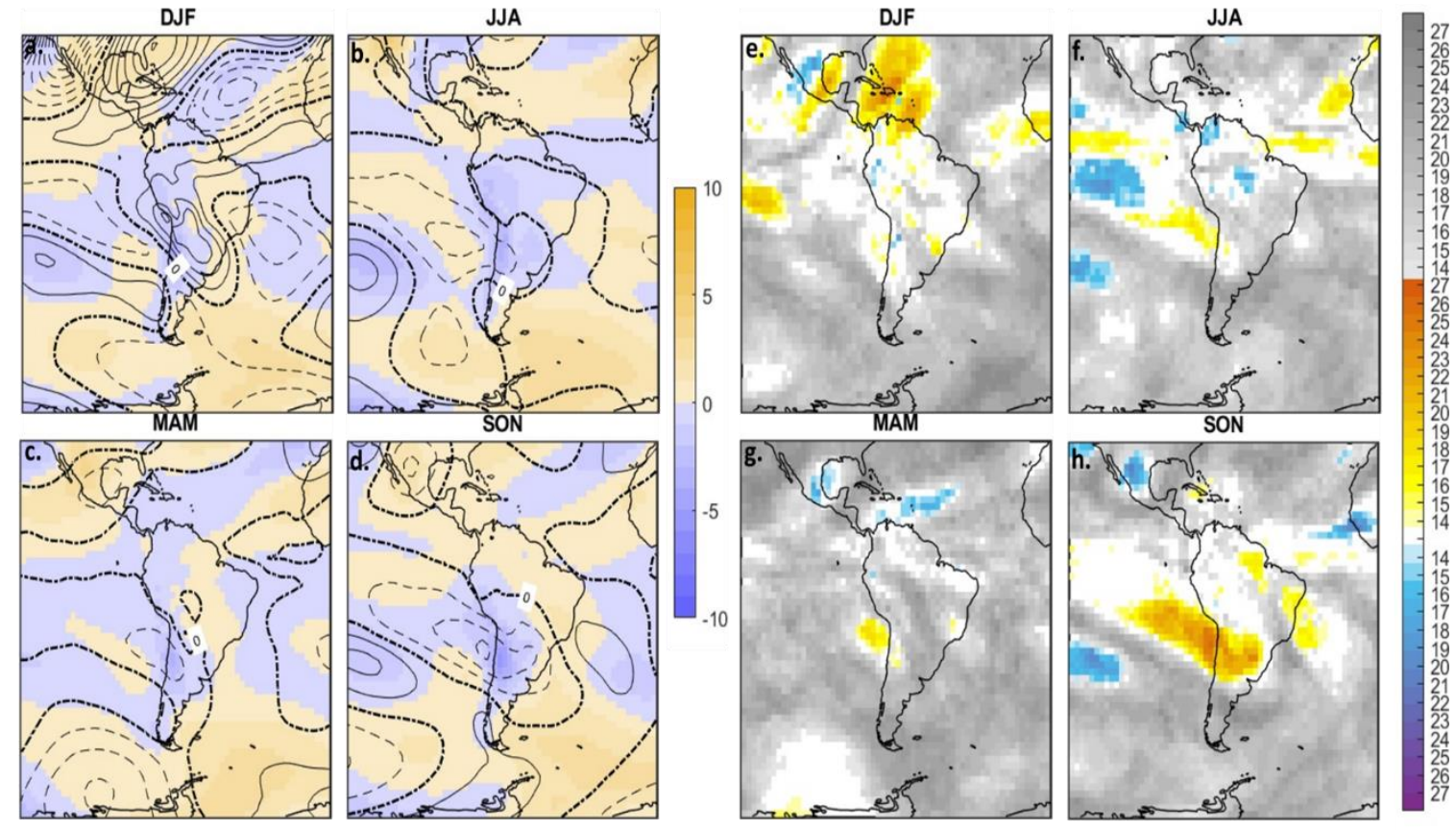

Figure 10: Same as Figure 9 but for $500 \mathrm{hPa}$ meridional wind. 

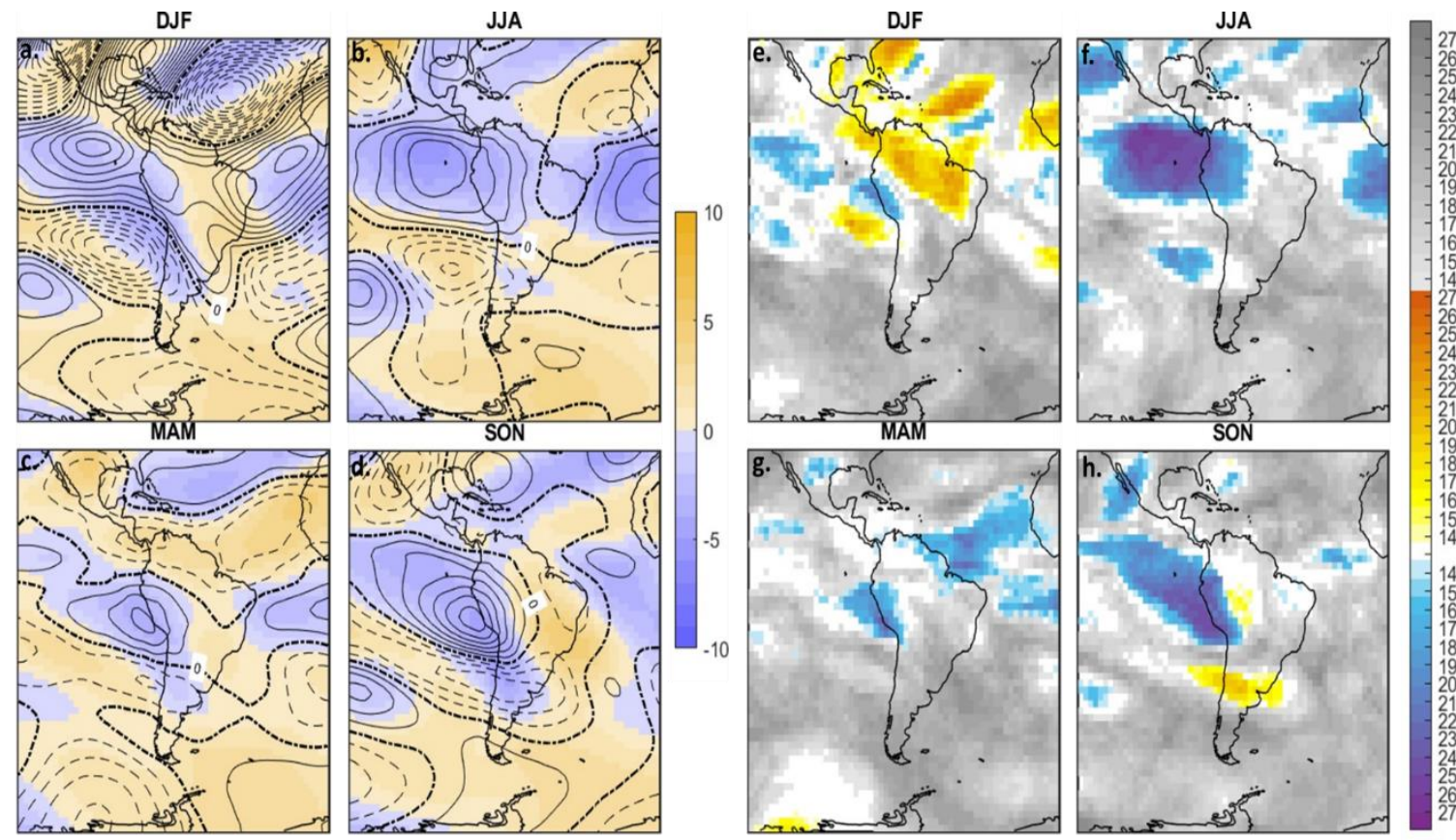

Figure 11: Same as Figure 9 but for $250 \mathrm{hPa}$ meridional wind. 


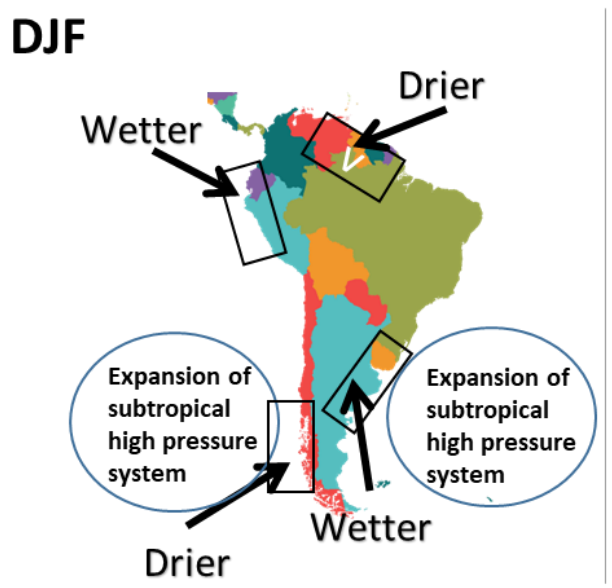

JJA

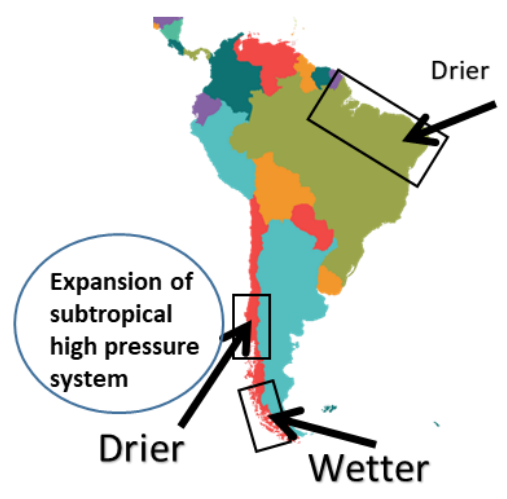

\section{MAM}

\section{SON}
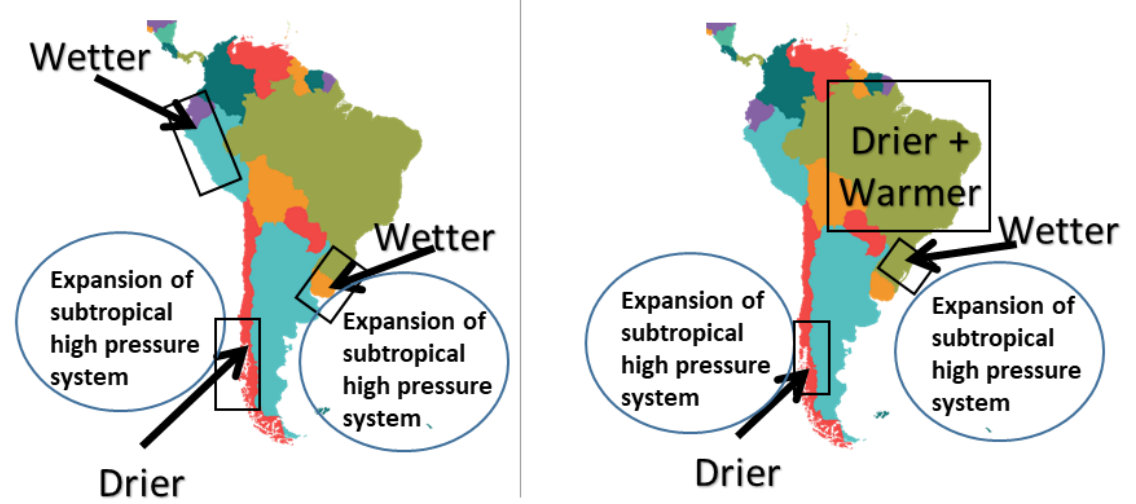

Figure 12: Summary of changes for the end of the $21^{\text {st }}$ century. 


\section{Bibliography}

Barkhordarian, A., H. von Storch, A. Behrangi, P. C. Loikith, C. R. Mechoso, and J. Detzer, 2018: Simultaneous Regional Detection of Land-Use Changes and Elevated GHG Levels: The Case of Spring Precipitation in Tropical South America. Geophysical Research Letters, 45, 6262-6271, https://doi.org/10.1029/2018GL078041.

Barkhordarian, A., S. S. Saatchi, A. Behrangi, P. C. Loikith, and C. R. Mechoso, 2019: A Recent Systematic Increase in Vapor Pressure Deficit over Tropical South America. Scientific Reports, 9, 1-12, https://doi.org/10.1038/s41598-019-518578.

Barros, V. R., and M. E. Doyle, 2018: Low-level circulation and precipitation simulated by CMIP5 GCMS over southeastern South America. International Journal of Climatology, 38, 5476-5490, https://doi.org/10.1002/joc.5740.

Bengtsson, L., K. I. Hodges, and E. Roeckner, 2006: Storm Tracks and Climate Change. J. Climate, 19, 3518-3543, https://doi.org/10.1175/JCLI3815.1.

Berman, A. L., G. Silvestri, and R. Compagnucci, 2012: Eastern Patagonia Seasonal Precipitation: Influence of Southern Hemisphere Circulation and Links with Subtropical South American Precipitation. J. Climate, 25, 6781-6795, https://doi.org/10.1175/JCLI-D-11-00514.1. 
Boisier, J. P., P. Ciais, A. Ducharne, and M. Guimberteau, 2015: Projected strengthening of Amazonian dry season by constrained climate model simulations. Nature Climate Change, 5, 656-660, https://doi.org/10.1038/nclimate2658.

Cabré, M. F., S. Solman, and M. Núñez, 2016: Regional climate change scenarios over southern South America for future climate (2080-2099) using the MM5 Model. Mean, interannual variability and uncertainties. Atmósfera, 29, 35-60, https://doi.org/10.20937/ATM.2016.29.01.04.

Chen, Y., B. Langenbrunner, and J. T. Randerson, 2018: Future Drying in Central America and Northern South America Linked With Atlantic Meridional Overturning Circulation. Geophysical Research Letters, 45, 9226-9235, https://doi.org/10.1029/2018GL077953.

Collow, A. B. M., M. A. Miller, and L. C. Trabachino, 2016: Cloudiness over the Amazon rainforest: Meteorology and thermodynamics. Journal of Geophysical Research: Atmospheres, 121, 7990-8005, https://doi.org/10.1002/2016JD024848.

de Carvalho, L. M. V., and I. F. A. Cavalcanti, 2016: The South American Monsoon System (SAMS). The Monsoons and Climate Change: Observations and Modeling, L.M.V. De Carvalho and C. Jones, Eds., Springer Climate, Springer International Publishing, 121-148.

Demaria, E. M. C., E. P. Maurer, B. Thrasher, S. Vicuña, and F. J. Meza, 2013: Climate change impacts on an alpine watershed in Chile: Do new model projections 
change the story? Journal of Hydrology, 502, 128-138,

https://doi.org/10.1016/j.jhydrol.2013.08.027.

Espinoza, L., 2015: NASA Finds Good News on Forests and Carbon Dioxide. NASA,. http://www.nasa.gov/jpl/nasa-finds-good-news-on-forests-and-carbon-dioxide (Accessed October 28, 2019).

Exbrayat, J.-F., and M. Williams, 2015: Quantifying the net contribution of the historical Amazonian deforestation to climate change. Geophysical Research Letters, 42, 2968-2976, https://doi.org/10.1002/2015GL063497.

Findell, K. L., P. Gentine, B. R. Lintner, and C. Kerr, 2011: Probability of afternoon precipitation in eastern United States and Mexico enhanced by high evaporation. Nature Geoscience, 4, 434-439, https://doi.org/10.1038/ngeo1174.

Fu, R., L. Yin, W. Li, P. A. Arias, R. E. Dickinson, Lei Huang, Sudip Chakraborty, Katia Fernandes, Brant Liebmann, Rosie Fisher, and Ranga B. Myneni, 2013: Increased dry-season length over southern Amazonia in recent decades and its implication for future climate projection. PNAS, 110, 18110-18115, https://doi.org/10.1073/pnas.1302584110.

Garreaud, R., 2009: The Andes Climate and Weather. Adv. Geosci, 22, 3-11, https://doi.org/10.5194/adgeo-22-3-2009.

Garreaud, R. D., M. Vuille, R. Compagnucci, and J. Marengo, 2009: Present-day South American climate. Palaeogeography, Palaeoclimatology, Palaeoecology, 281, 180-195, https://doi.org/10.1016/j.palaeo.2007.10.032. 
Junquas, C., C. Vera, L. Li, and H. Le Treut, 2012: Summer precipitation variability over Southeastern South America in a global warming scenario. Clim Dyn, 38, 18671883, https://doi.org/10.1007/s00382-011-1141-y.

Marengo, J. A., M. W. Douglas, and P. L. S. Dias, 2002: The South American low-level jet east of the Andes during the 1999 LBA-TRMM and LBA-WET AMC campaign. Journal of Geophysical Research: Atmospheres, 107, LBA 47-1-LBA 47-11, https://doi.org/10.1029/2001JD001188.

Marengo, J. A., W. R. Soares, C. Saulo, and M. Nicolini, 2004: Climatology of the LowLevel Jet East of the Andes as Derived from the NCEP-NCAR Reanalyses: Characteristics and Temporal Variability. J. Climate, 17, 2261-2280, https://doi.org/10.1175/1520-0442(2004)017<2261:COTLJE>2.0.CO;2.

Marengo, J. A., R. Jones, L. M. Alves, and M. C. Valverde, 2009: Future change of temperature and precipitation extremes in South America as derived from the PRECIS regional climate modeling system. International Journal of Climatology, 29, 2241-2255, https://doi.org/10.1002/joc.1863.

Marengo, J. A., and Coauthors, 2012: Development of regional future climate change scenarios in South America using the Eta CPTEC/HadCM3 climate change projections: climatology and regional analyses for the Amazon, São Francisco and the Paraná River basins. Clim Dyn, 38, 1829-1848, https://doi.org/10.1007/s00382-011-1155-5.

Marengo, J. A., Chou, S. C., Torres, R. R., Giarolla, A., Alves, L. M., \& Lyra, A. 2014: 
Climate change in central and South America: recent trends, future projections, and impacts on regional agriculture.

Marengo, J. A., C. M. J. Souza, K. Thonicke, C. Burton, K. Halladay, R. A. Betts, L. M. Alves, and W. R. Soares, 2018: Changes in Climate and Land Use Over the Amazon Region: Current and Future Variability and Trends. Front. Earth Sci., 6, https://doi.org/10.3389/feart.2018.00228.

Raia, A., and I. F. A. Cavalcanti, 2008: The Life Cycle of the South American Monsoon System. J. Climate, 21, 6227-6246, https://doi.org/10.1175/2008JCLI2249.1.

Schulz, N., J. P. Boisier, and P. Aceituno, 2012: Climate change along the arid coast of northern Chile. International Journal of Climatology, 32, 1803-1814, https://doi.org/10.1002/joc.2395.

Seidel, J., Q. Fu, J. Randel, and J. Reichler, 2008: Widening of the tropical belt in a changing climate. Nature Geoscience, 21-24, https://doi.org/10.1038/ngeo.2007.38.

Seneviratne, S. I., T. Corti, E. L. Davin, M. Hirschi, E. B. Jaeger, I. Lehner, B. Orlowsky, and A. J. Teuling, 2010: Investigating soil moisture-climate interactions in a changing climate: A review. Earth-Science Reviews, 99, 125-161, https://doi.org/10.1016/j.earscirev.2010.02.004. 
Sierra, J. P., P. A. Arias, and S. C. Vieira, 2015: Precipitation over Northern South America and Its Seasonal Variability as Simulated by the CMIP5 Models. Advances in Meteorology, https://doi.org/10.1155/2015/634720.

Soares, D., H. Lee, P. Loikith, A. Barkhordarian, and C. Mechoso, 2016: Can significant trends be detected in surface air temperature and precipitation over South America in recent decades?: CURRENT TEMPERATURE AND PRECIPITATION TRENDS OVER SOUTH AMERICA. International Journal of Climatology, 37, https://doi.org/10.1002/joc.4792.

Taylor, Karl E., Ronald J. Stouffer, and Gerald A. Meehl, 2011: “An Overview of CMIP5 and the Experiment Design.” Bulletin of the American Meteorological Society, 93, 4, 485-98. https://doi.org/10.1175/BAMS-D-11-00094.1.

Vera, C., G. Silvestri, B. Liebmann, and P. Gonzalez, 2006: Climate Change Scenarios for Seasonal Precipitation in South America from IPCC-AR4 Models. Geophysical Research Letters - GEOPHYS RES LETT, 33, https://doi.org/10.1029/2006GL025759.

Vicuña, S., R. D. Garreaud, and J. McPhee, 2011: Climate change impacts on the hydrology of a snowmelt driven basin in semiarid Chile. Climatic Change, 105, 469-488, https://doi.org/10.1007/s10584-010-9888-4.

Vincent, L. A., and Coauthors, 2005: Observed Trends in Indices of Daily Temperature Extremes in South America 1960-2000. J. Climate, 18, 5011-5023, https://doi.org/10.1175/JCLI3589.1. 
Yin, J. H., 2005: A consistent poleward shift of the storm tracks in simulations of 21st century climate. Geophysical Research Letters, https://doi.org/10.1029/2005GL023684@10.1002/(ISSN)19448007.ATMOSLINKAGES1.

Yin, L., R. Fu, E. Shevliakova, and R. E. Dickinson, 2013: How well can CMIP5 simulate precipitation and its controlling processes over tropical South America? Clim Dyn, 41, 3127-3143, https://doi.org/10.1007/s00382-012-1582-y.

Zanin, P. R., and P. Satyamurty, 2020: Hydrological processes interconnecting the two largest watersheds of South America from multi-decadal to inter-annual time scales: A critical review. Int. J. Climatol., DOI:10.1002/joc.6442.

Zazulie, N., M. Rusticucci, and G. B. Raga, 2018: Regional climate of the Subtropical Central Andes using high-resolution CMIP5 models. Part II: future projections for the twenty-first century. Clim Dyn, 51, 2913-2925, https://doi.org/10.1007/s00382-017-4056-4.

Zilli, M. T., L. M. V. Carvalho, and B. R. Lintner, 2019: The poleward shift of South Atlantic Convergence Zone in recent decades. Clim Dyn, 52, 2545-2563, https://doi.org/10.1007/s00382-018-4277-1.

Zipser, E. J., D. J. Cecil, C. Liu, S. W. Nesbitt, and D. P. Yorty, 2006: Where are the most intense thunderstorms on earth? Bull. Amer. Meteor. Soc., 87, 1057-1072, https://doi.org/10.1175/BAMS-87-8-1057. 